H. V. Vdovychenko, Doctor of Philosophical Science, Associate Professor Taras Shevchenko National University of Kiev, 60, Volodymyrska Street, Kyiv, 01033, Ukraine

\title{
CULTURAL AND PHILOSOPHICAL ORIGINS AND ATTITUDES OF THE EARLY WORKS OF P. TYCHYNA: "THE LAST SUPPER, GUILLOTINE DAYS"
}

The article explores cultural and philosophical origins and attitudes of the early works of P. Tychyna, namely defining the ones events and phenomena of domestic and foreign ethnocultural and professional cultural life, cultural and philosophical ideas and teachings, as well as $P$. Tychyna's own cultural and philosophical views, revealed mainly in his poetry books of 1918 - 1924 . One of the most important, but still littleknown pages of the biography and ideological and artistic evolution of $P$. Tychyna is the formation during the first third of the twentieth century, fundamental for his entire life cultural and philosophical guidelines of early creativity. The study of this problem is closely connected with the long overdue need for unbiased systematic classification and consideration of the whole spectrum of cultural and philosophical sources and guidelines of ideological and artistic evolution of the poet of ideologically contradictory poems-myths of Ukrainian national renaissance and enslavement "Golden Homin" as a sacred figure-symbol of modernism and, at the same time, social realism in Ukrainian literature, the most famous and, at the same time, the most criticized domestic artist-model of evaluative polarity of official and public myth-making in the USSR and, later, in Ukraine. In light of the assessment of the main achievements of tychynology, a cultural-philosophical-literary analysis of the three stages of the ideological and artistic evolution of $P$. Tychyna of this period was carried out. These stages are: 1. formation (Kyiv-Chernyhiv): 1906 - 1916; 2 creative rise and blossoming (Kyiv): 1917 - 1921; 3. decline and crisis (Kyiv-Kharkiv): 1922 - 1929. Two groups of origins of the poet's early works were examined. The first one is represented by domestic and foreign ethnocultures and consists of three subgroups of folklore: 1. Ukrainian; 2. foreign (of other Slavic peoples); 3. foreign, mainly of the peoples of the Near and Middle East (Armenian, Turkish and Indian). The second group is represented by domestic and foreign professional cultures, the last of which is divided into three subgroups: 1. Russian; 2. European and North American; 3. Eastern (the Near, Middle and Far East). P. Tychyna was a symbol and myth of modernism and Socialist realism in the literature and culture of the Ukrainian SSR, and the early stages of his cultural and philosophical credo's evolution from the neopagan-Christian Ukrainian national-patriotic myth to the national-communist pantheistic-materialistic cosmogony.

Key words: cultural philosophy, tychynology, early creativity of P. Tychyna, myth, mythmaking, literature of the Ukrainian SSR of the Shooted Renaissance era, the Modern era, the Postmodern era, the Socialist Realism.

Г. В. Вдовиченко, д-р филос. наук, доц.

Киевский национальный университет имени Тараса Шевченко,

ул. Владимирская, 60, г. Киев, 01033, Украина

\section{КУЛЬТУРФИЛОСОФСКИЕ ИСТОКИ И УСТАНОВКИ РАННЕГО ТВОРЧЕСТВА П. ТЫЧИНЫ: "ТАЙНАЯ ВЕЧЕРЯ, ГИЛЬОТИННЫЕ ДНИ"}

В статье исследованы культурфилософские истоки и установки раннего творчества П. Тычины, а именно как обуславливающие его события и явления отечественной и зарубежной этно- и профессионально-культурной жизни, культурфилософские идеи и учения, так и явленные в произведениях поэта первой трети XX в., в основном в книгах стихов 1918-1924 ге., культурфилософские взаляды. В свете оценки главных достижений тычиноведения проведено культурологическо-философско-литературоведческое изучение трех этапов идейно-художественной эволюции П. Тычины этого периода: 1. становления (черниговско-киевский): 1906-1916; 2. творческого подъема и расивета (киевский): 1917-1921; 3. упадка и кризиса (киевско-харьковский): 1922-1929, - и рассмотрены две группы источников формирования культурфилософских установок его раннего творчества. Первая - отечественная и зарубежные этнокультуры в составе трех подгрупп фольклора: 1. украинского; 2. зарубежного (другие славянские народы); 3. зарубежного, главным образом народов Ближнего и Среднего Востока (армянский, турецкий, индийский). Вторая - отечественная и зарубежные профессиональные культуры, которые поделены на подеруппы: 1. русскую; 2. европейскую и североамериканскую; 3. восточную (Ближний, Средний, Дальний Восток). Воспроизведены и освещены ранние этапы эволюции культурфилософского кредо П. Тычины - творца-символа и мифа модернизма и соцреализма в литературе и культуре УССР: от неоязыческо-христианского украинского националпатриотического мифа к национал-коммунистической пантео-материалистической космогонии.

Ключевые слова: культурфилософия, тычиноведение, раннее творчество П. Тычины, миф, мифотворчество, литература УССР эпохи "Расстрелянного Возрождения", модерн, постмодерн, соцреализм.

А. І. Кретов, канд. філос. наук, ст. викл. Національна академія образотворчого мистецтва і архітектури, вул. Вознесенський узвіз, 20, м. Київ, 04053, Україна creteil12@gmail.com

\section{СПАДЩИНА ТАРАСА ШЕВЧЕНКА: ОБРАЗ "МИТЦЯ-ПРОРОКА" В УКРАЇНСЬКІЙ КУЛЬТУРІ}

Присвячено проблемі образу митця як пророка у зв'язку з творчістю Т. Шевченка, унаслідок його безпрецедентної впливовості в українській культурі. Формування цього образу є результатом взаємодії соціокультурних факторів, які іє предметом аналізу в цій статmі. По-перше, це підпорядкування самовизначення Великого Кобзаря тим стратегіям, які залежать від поезії та живопису, місця цих сфер у тогочасному суспільстві, завдання ними міри інтегрованості творчої діяльності в соціальну структуру та мистецьке середовище, значення в них майстерності та замовлення. По-друге, відлуння в шевченкову епоху ідей Просвітництва із їхніми універсалістськими претензіями та становлення в Російській імперії феномену, який отримав назву "інтелігенція", що формувався на тлі культурного "літературоцентризму". Потретє, вплив романтизму на ідею очолення митцем процесу формування певної спільноти, яка не пов'язана із соціальною нерівністю та формальними ієрархіями в суспільстві. По-четверте, залежність образу мития-пророка з переплетенням християнських і язичницьких коренів украйнської культури. Показано, що в послідовників $T$. Шевченка створений ним архетип національного мития-пророка пережив ситуації наслідування, ствердження, переосмислення, навіть заперечення. Такий різноманітний діалог свідчить про актуальність спадщини Т. Шевченка.

Ключові поняття: митець як пророк, поет, спільнота, суспільство, інтелігенція, літературоцентризм.

Постановка проблеми. Знаменна для українського суспільства й культури подія 200-річчя 3 дня народження Т. Г. Шевченка сталася, здавалося б, зовсім недавно, але скільки драматичних подій відбулося з тих пір в Україні! Ювілей був не тільки хронологічною віхою, але й поштовхом для пошуків нових значень щодо особистості великого поета, його життєвого шляху та творчої спадщини, намагань осягнути все це у взаємозв'язку, цілісності й багатогранності. Тарас Шевченко для України перший, хто відповідає фрормулі $Є$. Євтушенка щодо 
феномену російського поета, який "більше, ніж поет". Адже вона стосується специфіки національного відродження багатьох слов'янських народів. Зрозуміло, що упередженість щодо нього, категоричність у критиці його творчості, "шевченкофобія", яку проаналізував у своїй книзі І. Дзюба, набуває не тільки фрілологічного або культурологічного, але й ідеологічного значення. Видана півтора десятиріччя тому, книга характеризує це явище як цілісний проєкт в межах економічної, інформативної, культурної імперської експансії, роблячи висновок: "Воюючи з Шевченком, воюють з Україною. Хоч і приховують це 3 різною мірою вправності" [10, с. 55]. Особливо показовим щодо шевченкофобії $\epsilon$ сюжет Оренбурзького телебачення, створений шість років тому для програми "Вести". Автор здивований "надмірним" вшануванням поета, яке відбувається з року в рік. Адже він, мовляв, нічим саме Оренбург не уславив, отже, чому витрачаються кошти на прийом гостей з України? Зі слів цих "експертів" Шевченко постає "русофобом", "другорядним поетом", "удаваним страждальцем". Пропонується фото часів II світової війни, де портрет Великого Кобзаря розташований поруч зі свастикою, задля того щоб його спадщина асоціювалася з колабораціонізмом [21], а українська ідея - з націонал-соціалізмом. Коментарі зайві. Аналогічні феномени сучасних 3MІ можуть бути вагомим аргументом проти тих, хто залюбки ототожнює "російське" (в його сучасних найгірших імперських проявах) і "радянське". Адже в Радянському Союзі з його (хоч й ідеологізованим) культом Т. Шевченка - захисника трудящих така передача не тільки не могла бути підготованою, вона була просто немислимою.

Тарас Шевченко свого часу пережив піввікову боротьбу проти нього та його поетичної творчості з боку російського авторитаризму, часткове визнання, офріційне приниження, вслід за якими відбулося офріційне радянське звеличення. Різні політичні сили позиціонували його як революціонера-демократа і національного революціонера, атеїста і побожну людину. Навіть зі ставленням до Т. Шевченка монархічних сил не все однозначно. Так, останнім часом досліджено матеріали про парадоксальний культ Шевченка в середовищі малоросів-монархістів початку XX ст., який робив наголос на його "консерватизмі", релігійності, вишукував у нього антипольські та антисемітські риси [24]. Для такої парадоксальної інтерпретації треба було замовчувати те, що було стрижневим для поета (заперечення царизму, соціальної нерівності, клерикалізму). Тим не менш надто великим було бажання заради відданості місцевому патріотизмові, поєднаному з лояльністю щодо імперської влади, зробити поета "своїм", до того ж шляхом, який йде всупереч з істиною.

Аналіз досліджень і публікацій. До образу Пророка у спадщині Тараса Шевченка дослідники весь час повертаються. Одними вченими він розглядається як домінуючий (Г. Грабович, О. Пріцак), іншими - поряд с цілою низкою різноманітних образів, завдяки яким він присутній в суспільній свідомості ("кобзар", "всенародний кожушаний батько", "сокирник", "гайдамака", "богоборець"). Є. Маланюк, наприклад, у своєму сонеті "Шевченко" наголошує на обмеженості для харизматичної постаті Т. Шевченка загальноприйнятих його характеристик ("поет", "трибун", "Кобзар Тарас"). Величезний узагальнюючий матеріал дає для осмислення творчості й образа великого митця видана до його 200-річного ювілею Шевченківська енциклопедія. В ній розглядаються відлуння постаті митця у мотивах та образахконцептах шевченківських творів, в українській та світовій літературі, живописі, публіцистиці, нові методологічні підходи до його творчості. Сучасними українськими дослідниками проаналізовано рецепцію творів і особистості поета окремими митцями та представниками літературно-художніх напрямків, аудиторією відвідувачів шевченківських музеїв. Постать Тараса Шевченка розглядається в контексті стратегії сучасного національнодержавного розвитку. За сторінками змістовного двотомника "Тарас Шевченко в критиці", виданого під загальною редакцією Г.Грабовича, можна простежити характер реакцій на творчість та постать поета за його життя та протягом року після його смерті. Адже саме тоді закладалися основи образів митця, які згодом стали домінуючими в українській, російській, польській культурах.

Релігійні засади творчості Великого Кобзаря взагалі та християнські зокрема розкриваються у працях І. Дзюби, Д. Степовика. Щодо постаті і творчості Т. Шевченка вперше в українському літературознавстві були застосовані звичайні для західної науки архетипно-міфологічний підхід К. Г. Юнга, структурна антропологія К. Леві-Строса (Г. Грабович, О.Гриценко, О. Забужко, А. Шестак). Такий підхід часом викликає рішуче і палке заперечення аж до звинувачення у "фальсифікації" постаті та творчості Тараса Шевченка, але подібна риторика інколи нагадує прийоми попередньої епохи (П. Іванишин) [16].

Важливою проблемою для виявлення способу самовизначення Тараса Шевченка $€$ співвідношення в його діяльності і світогляді ролей поета і художника (Д. Антонович, Л. Генералюк, О. Пріцак) [1; 5; 22]. У розумінні того, яке значення надається образу "митецьпророк" в українській культурі після Т. Шевченка (І. Франко, В. Винниченко, Леся Українка), важливу роль грають монографії Я. Грицака, Л. Демської-Будзуляк, Г. Сиваченко. Спадщині Шевченка надається також важлива роль у наративних практиках, що стверджують українську ідентичність.

Філософсько-методологічні засади аналізу Шевченкової творчості на тлі української культури розглядалися у колективній монографії Інституту фрілософії. Релігійно-фрілософським та соціокультурним аспектам поглядів Т. Шевченка та їх значенню для України присвячені посібники, монографії, змістовні статті (О. Білий, М. Бойко, В. Скуратівський, В. Сулима та інші), в яких виявляються нові грані образу митця.

Попри різноманітність і глибину досліджень творчості й особистості Т. Шевченка, розгляд в різних вимірах його пророчої місії (через образи-концепти, міфи, архетипи, поетику, засоби репрезентації та саморепрезентації митця) необхідним $є$ комплексний філософськокультурологічний аналіз образу "митець-пророк", який, на нашу думку, є ключовим не тільки для характеристики Т. Шевченка, а й для того відлуння, яке мала його постать в українській культурі. Особливо важливим $є$ це для нових вимірів художнього пізнання і втілення особистості митця. Нинішня стаття $€$ поглибленням матеріалів, використаних автором для низки публікацій у педагогічному часописі, що видавався на території Російської Федерації, в яких розглядався зв'язок творчості Г. Сковороди, М. Костомарова, Т. Шевченка [31], Лесі Українки з християнськими цінностями. Статті викликали певний інтерес, але це було вже півтора десятки років тому, і з тих пір соціокультурна ситуація, на жаль, змінилася...

Мета статті. Для розуміння образа митця-пророка у творчості Т. Шевченка з філософрько-культурологічної точки зору, його впливу на українську культуру доцільно врахувати такі аспекти:

по-перше, співвідношення постаті "митець-пророк" у творчості Т. Шевченка 3 тими альтернативними моделями самовизначення, які залежать від видової специфіки мистецтва, особистості митця, його життєвих та 
творчих стратегій, міри інтегрованості митця в соціальну структуру та мистецьке середовище;

по-друге, відлуння у Шевченковому "пророчому дискурсі" ідей епохи Просвітництва та процесу формування френомену інтелігенції в Російській імперії;

по-третє, витоки образу "митець-пророк" в творчості Шевченка, пов'язані з епохою романтизму;

по-четверте, вкоріненість образу "митця-пророка" у східнослов'янському язичництві й сформованому у православ'ї особливому сакральному ставленні до слова.

Виклад основного матеріалу дослідження. Образ митця 3 давніх-давен характеризувався з урахуванням в його діяльності, з одного боку, духовно-світоглядного, 3 іншого - практичного, формоутворюючого аспекту. Але тільки впродовж XIX ст. формується інтегральний образ Митця як представника єдиної сфери Мистецтва, незалежно від того чи іншого виду та жанру. Зі стародавніх часів існувала традиція, згідно з якою концепція божественної інспірації (лат. - натхнення) була наслідком віри в сакральне походження саме поезії. Ідея одержимості, безумства поетів поділяється Гераклітом, Емпедоклом, втілюється в культі Діоніса й, нарешті, філософськи обґрунтовується Платоном як "несамовитість", що послана музами і $є$ вищою за розсудливість. Поет, згідно з Платоном, творить під впливом надприродних сил, в тих, кого Бог робить віщунами і пророками, він віднімає розум, перетворюючи на своє знаряддя. У переддень Французької революції кінця XVIII ст. постать літератора-пророка в європейській культурі була досить впливовою, хоча поступово втрачала зв'язок з релігією. У Біблійній енциклопедії для визначення поняття "пророк" використовуються такі важливі моменти, як посередництво між світами; розкриття того, що $є$ прихованим для звичайних людей; правдивість послання, за яке пророк може поплатитися життям; дане згори вміння передбачати майбутнє і відрізняти добро від зла, а головне донести це все до людей $[4$, с. 583]. Ще слід додати, що, згідно з Писанням, пророки покликані Богом, тобто пророкування виступає як дар та покликання вище, але не як власне рішення самого пророка [13].

Щоб зрозуміти образ митця, з яким самоототожнювався Тарас Шевченко й в якому його сприймала публіка, слід знайти витоки як ідейних та інституційних впливів, так і енергії протистояння, що дали життя поезії Великого Кобзаря.

Слушним щодо розуміння моделі самовизначення Т. Шевченка $є$ зауваження Лесі Генералюк про диспропорцію між галузями шевченкознавства: літературознавчим та мистецтвознавчим. Хоч це й, на думку дослідниці, "мало хвилює тих, хто цікавиться Шевченком", але те, що вважають нормою, є насправді цілковитою аномалією, небажанням нації прочитати свого аполога і пророка цілісно. "Поет Шевченко аж ніяк не втратить своєї значущості на тлі профресійного художника Шевченка" [5, с. 6]. Л. Генералюк приєднується до тих, хто заперечує твердження про нібито незначну мистецьку цінність художнього доробку Т. Шевченка, слабке ідейне наповнення його портретів, пейзажів порівняно з поетичними закликами, інвективами, пророцтвами [9, с. 9].

Існують різні підходи до співвідношення в особі Т. Шевченка поета і художника.

Дмитро Антонович (чия праця довгий час залишалася найкращим дослідженням творчості Шевченкахудожника) робив акцент не на протиставленні, а на взаємодоповненні в творчості і долі Т. Шевченка постатей поета та художника, він вважав, що його художній талант був недооцінений. Він також наполягав на тому, що живописні твори Великого Кобзаря майже ніколи не були ілюстрацією до його творів поетичних, тобто не мали "службового", "підпорядкованого" характеру [2]. О. Пріцак намагається пояснити доленосний вибір Т. Шевченка на користь поезії не тільки особистими вподобаннями, але до того ще й особливим месіанізмом, який супроводжував постать поета в очах суспільства порівняно з художником. На противагу сприйняттю освіченою громадськістю "аури" поета, у самовизначенні художника вагомим був професіоналізм, майстерність та залежність від замовника. Л. Генералюк поглиблює розуміння співвідношення двох галузей Шевченкової творчості, вважаючи, що як поет-пророк Т. Шевченко більше сповнений песимізму, а як художник він більш гармонійний [9]. Для порівняння двох типів Шевченкових текстів, художніх та поетичних, доцільно звернутися до Еріха Ауербаха. Дослідник проаналізував дві моделі текстів, які він вважав засадничими для європейської культури, - гомерівські та біблійні. Перші $є$ тілесно-гармонійними, оповідними, тяжіючими до античного класичного світогляду з його пластичністю. Біблійні тексти пророчо-драматичні, з символами, притчами, недомовленістю [1]. Зіставляючи ці два типи текстів з творчістю Тараса Шевченка, можна сказати, що "класично-античний" погляд на світ переважає в його образотворчій спадщині, а "пророчо-драматичний" - у поетичній. Не спрощуючи всю різноманітність творчого доробку Тараса Шевченка в царині образотворчого мистецтва, можна зробити висновок, що його живопис і графіка більш були пов'язані зі школою, академічною традицією, вдосконаленням майстерності, експериментами з техніками офорту, які він запроваджував в Росії вперше. Все це слугувало створенню зримої гармонії світу. В поезії ж більшою мірою знайшла відображення містично-пророча, втаємничена частина його сутності. Значну роль в Шевченковій поетичної творчості відіграє діалог з біблійними текстами, образи пророків та віршовані перекази біблійних псалмів.

Відчуття свого особливого культурного призначення, дух месіанства, який існував у поетів і літераторів Російської імперії, можуть бути зрозумілими, якщо простежити генезис соціальної групи, за якою у другій половині XIX ст. затвердилася назва "інтелігенція". Великий поштовх формуванню цієї групи надало зростання ролі в імперії після епохи Богдана Хмельницького вихідців 3 України, тенденція, яка після реформ Петра I тільки посилилася. Радикальність змін і велика потреба у фахівцях (інженерах, архітекторах, навігаторах), а також гуманітаріях-ідеологах згуртувала прошарок освічених людей навколо царської влади, створила культ постаті царя як культуртрегера, деміурга нової країни. Культ цей був неодноразово засвідчений у панегіричній поезії, породив величезну кількість віршів.

Ю. Лотман писав про те, що врешті-решт соціальна структура суспільства, яка забезпечила розквіт російської культури XIX ст., робила вільними людьми з правами, на кшталт тих, які гарантувала Французька революція, тільки дворянство. Базувалося забезпечення цих прав на покріпаченні основної маси селянського населення. Таке поєднання прав і вольностей та певного культурного рівня у верхів з уярмленням низів чимось нагадувало, на думку Ю. Лотмана, античне суспільство (імперію Стародавнього Риму). Втім велике коло освічених людей рішуче відмежувалося від дворянства і чиновництва внаслідок бачення прірви між європейськими ідеалами і кріпосницькими методами їх втілення, при цьому взявши на себе місію морального виховання і перетворення як вищої влади, так і суспільства через освіту, літературу, мистецтво, журналістику. Це коло людей стверджувало свою перевагу перш за все над дворянством у сорері утворення цінностей та смислів, 
попри всі його політико-правові та економічні привілеї та знатність походження. Поняття "інтелігенція", завдяки якому це коло себе ототожнювало, не має аналога в європейських мовах [16]. Саме до цієї групи людей поступово усвідомлював свою причетність Тарас Шевченко.

Спрямованість на монументальне уславлення культуртрегерства і міці царської влади була висміяна Т. Шевченком у поемі "Сон". Важка рука "Мідного вершника", велич імперської класики, що слугувала владі, яка, в тому числі через Академії, продукувала фахівців для власного звеличення, раптом викликала у селянина-кріпака бажання не стільки вписатися в цю систему "соціального замовлення", скільки висловити палкий протест, спираючись на поетично сформульований пророчий дискурс.

Характерним було те, що Бєлінський, представник російської інтелігенції та універсалізму Просвітництва та його пророчого дискурсу, з цієї позиції розгорнув критику як Шевченка, так і Гоголя. Якщо першого він рішуче відкидав за його "містечковий діалект" та "хохляцький патріотизм", то другого - за підтримку реакційних сил в його публіцистиці. Несприйняття "партикуляризму" Т. Шевченка пересилювало весь той демократизм, який, здавалося б, міг би й об'єднати поета з відомим літературним критиком. Попри те, що В. Бєлінський був проти сваволі поміщицтва, гніту держави, клерікалізму, заради протистояння "відсталому" Т. Шевченку він був готовий солідаризуватися з урядом в його боротьбі з Великим Кобзарем. Тут він поводив себе, так би мовити, "по-панському". Напевно, він солідаризувався б із діячем епохи Просвітництва Антуаном де Ріваролем (1753-1801), який вважав: "якщо неясно висловлене - отже, висловлене не французською мовою", з тою різницею, що "несамовитий Віссаріон" вважав літературу, написану "малоросійським наріччям", перешкодою об'єднуючій силі російської мови та прогресу в Російській імперії, а спроби відродити український народ - загрозою тенденціям поступу. Виявляється, що уряд для нього певною мірою - "більш європейська" сила, ніж український поет. Миколу Гоголя Бєлінський критикував за інше - за консервативне намагання перевиховати суспільство за допомогою церкви, релігії і начальства ("Вибрані місця з листування з друзями"), вихваляючи водночас за гостру сатиру на чиновництво й поміщицтво в його художніх творах. У Шевченка (поема "Сон") він сатиру на державний лад Росії категорично не сприймав, бо вона була написана "говіркою" й закріплювала, на його думку, партикулярне, "відстале", українське на противагу універсальному, "прогресивному", російському. Таким чином, В. Бєлінський був "плоть від плоті" тих фрранцузьких революціонерів, які викорінювали місцеві мови Франції під приводом того, що ті були "носіями реакції". "Малоросійське наріччя" Тараса Шевченка знецінювало в очах Бєлінського той сатиричний пафос поета, який російський "революціонер-демократ" (як його називали більшовики) так цінував у художніх творах Гоголя (рішуче відкидаючи його публіцистику).

Тарасу Шевченку зовсім був не чужий просвітницький пафос пізнання, оволодіння силами природи, ствердження людини "з низів" через талант, розум, енергію, працю, навчання, волю до життя - все це присутнє у Шевченковій прозі, автобіографрічних повістях "Художник" та "Музикант". Можна сказати, що тут Шевченко вихованець і спадкоємець тих літераторів епохи Просвітництва, які були вчителями і пророками у своєму суспільстві, беззастережними моральними авторитетами, які спрямовували своїх читачів у "царство розуму".

Коли в державі відсутні елементарні демократичні свободи і неможливо висловити певні ідеї з парламент- ської трибуни або університетської кафедри, література, за словами О. Герцена, стає єдиною трибуною, з якої народ може почути голос свого обурення і своєї совісті. Поет, письменник бере на себе тягар поєднання в єдиній особі фрілософа, мислителя, вчителя, який виступає від імені як універсальних, так і національно-особливих цінностей. У соціокультурному середовищі Російської імперії література завдяки своїй метафоричності, образності долає бар'єри цензури у політично безправному суспільстві (так звана "езопова мова"). Саме тому вона бере на себе фрнкції кількох складових культури, а саме: філософрії, соціальних наук, публіцистики, суспільнополітичної діяльності (опозиційної чи офріційної).

Романтизм як мистецька і соціокультурна течія справив великий вплив на східнослов'янські народи в цілому і Т. Шевченка зокрема. Це сталося внаслідок того, що він апелював до почуттів і серця на противагу розуму, а отже - до народної культури на противагу інституціалізованій культурі вищих класів. Але слід зазначити одну дуже важливу річ. У часи молодості Шевченка досить суттєво змінювався характер формулювання в ідеології суспільно-політичного устрою Російської імперії. В часи Петра I вона знаходила опору в радикальних модернізаційних змінах, при цьому слово "європейське" мало позитивне забарвлення, а "російське" - досить часто, навпаки, негативне, як уособлення того, що чинило опір владі. Потім з'явилася формула Уварова: православ'я, самодержавство, народність. Вона, всупереч петрівським реформам, передбачала опору на традицію [20, с. 705-707]. Захищаючи своє розуміння "народності", виступаючи посередником, пророком між нею та Богом, Т. Шевченко виступає проти двох інших опор держави: самодержавства й офріційної церкви. Оцінюючи глибинні виміри постаті митця-пророка, слід згадати сформульовану М. Вебером характеристику такого типу політичного панування, як "харизматичний лідер".

Послідовники М. Вебера наполягали на тому, що цей тип лідера стосується формально неінституціалізованої спільноти, в якій немає чітко визначених посад, привілеїв, економічних інтересів, спільноти, яка рухається вперед "не літерою, але духом". Тьоніс свого часу розрізняв Gemeinschaft та Gesellschaft як "спільноту" та "суспільство". Спільнота (на противагу суспільству) поєднується саме неформальними, прямими, особистісними, неопосередкованими, неінституціоналізованими зв'язками... Саме у такому протистоянні імперській ієрархічності та заорганізованості позиціонував свій народ Тарас Шевченко, коли церква стає просто додатком до держави, якій освячує будь-які злочини в ім'я державного Молоха і зростання його могутності, коли несправедливість, нерівність, експлуатація руйнують відносини між людьми. Один з лідерів кирило-мефодіївців, Микола Костомаров, писав у своїх мемуарах, як члени товариства намагалися одухотворити суспільство проповіддю, подібною до апостольської місії Кирила та Мефодія [18, с. 474-475]. Вони усвідомлювали себе невеличкою общиною однодумців, яка прагнула силою й чистотою своєї патріотичної енергії змінити імперський світ на братство слов'янських народів. Всупереч Гегелю, який надавав німцям пріоритет у сучасну йому епоху внаслідок їхніх талантів у створенні сучасної правової держави, кириломефродіївці намагалися ствердити новий дух у громаді справжній християнський дух на противагу формалізму, бюрократизму, класовості та ієрархічності.

Характерно, що М. Драгоманов (який, можна сказати, належав до покоління не романтиків, а позитивістів з їхньою вірою не в серце та щирі почуття, а в позитивну науку) критикував Тараса Шевченка саме як інтелігент, що виступає з просвітницьких позицій: він закидав 
йому відсутність в його поезії чіткої ідеологічної, заснованої на здобутках європейського соціалістичного руху програми [11, с. 327-430]. Таким чином, розуміння Т. Шевченка як "літератора-пропагандиста" у французькому чи російському дусі не дає осягнення сутності його творчості. Тлумачення митця в дусі соціальної чи національної ангажованості призводить, зазначив Г. Грабович, до "одномірності" у розумінні Т. Шевченка, заявивши, що Великий Кобзар передусім "поет-пророк", якого не можна звести до соціального або національного виміру, перетворюючи його тексти або у виклад Марксової теорії класової боротьби, або у струнку концепцію національної ідеї, або у єдино вірну, автентичну версію української історії. Саме романтизм в його цілісності був притаманний творчості Тараса Шевченка. Він стверджує щирість почуття - на противагу холодному розуму, народно-автентичне, істинно християнське єднання людей - на противагу бюрократично-ієрархічному, пригноблюючому. Тут присутній вже не месіанізм звужено просвітительський, а той, який звеличує особливості народів, коли людство сприймається, за Й. Гердером, як арфа, в звучанні якої важлива своєрідність звуку кожної струни. Сильна своїм пафосом заява щодо пророкування у Шевченковій творчості була зроблена Миколою Костомаровим у статті "Спогад про двох малярів", де поет характеризується як "провісник народних дум, представник народної волі, тлумач народного почуття" (розум, воля, почуття виступають тут як виміри покликання Тараса Шевченка) [17, с. 101-106].

Отже, нагальною залишається потреба вивчення постаті Шевченка у контексті світової культури, функціонування моделі "митець-пророк" як взагалі, так і у власній країні. Також актуальним $€$ надання цій проблемі філософської глибини. Необхідно осмислення моделей, завдяки яким намагалися залучити постать Шевченка до різноманітних ідеологій, тобто надати їй певну "площину" й "одновимірність". А "одновимірний" Тарас Шевченко - це модель, якою занадто легко маніпулювати.

3 точки зору цілісності образу Т. Шевченка як "поета-пророка" він $€$ фрігурою суперечливою. 3 одного боку, М. Драгоманов як представник "позитивістсько-наукового" покоління "синів" закидав Т. Шевченку наявність релігійної риторики і віджилих понять і відсутність близькості до сучасних соціалістичних теорій. 3 іншого боку, марними $є$ і спроби замовчати те, що поет не $є$ ортодоксальним (в широкому сенсі цього слова) християнином, бо в нього відсутня поштивість до інституту церкви як такої та присутні ноти соціально та морально орієнтованого богоборства.

Образ Т. Г. Шевченка як пророка розкривається новими гранями завдяки діалогу особистостей крізь віки. Особливо змістовним стає подібний діалог, коли уславлений український художник М. А. Стороженко намагається осягнути весь драматизм особистості і творчості Т. Шевченка не тільки завдяки пензлю, але й своєму художньому слову. Через це ілюстрації до "Кобзаря" у М. А. Стороженка перестають бути тільки ілюстраціями, вони вже, за словами Івана Дзюби, - це співтворчість, "діяння Шевченківської поезії й самого образу Шевченка, долі Шевченка - у душі естетично-чуйної і національно-відповідальної людини" [22, с. 11]. Осмислюючи образ Чернечої гори у Шевченка, М. А. Стороженко порівнює ії̈ з Небесним Синаєм, символікою Фудзіями у Хокусаї, таємницями Тибету і взагалі 3 можливістю "вбирати в себе живизну простору і вертикалі неба" [25, с. 8]. Подібний образ Шевченка-пророка в своїх пам'ятниках великому поету створює і скульптор Іван Кавалеридзе, використовуючи композиційну схему єднання людини і гори [20, с. 111]. Сповідуючись як художник перед Шевченковим "Автопортретом зі свічкою", в очах, зображених на картині, М. А. Стороженко не вбачає "революціонера", "бунтаря" або "демократа", які для нього є різновидами рабської свідомості. "Ні! - продовжує він. - Там блиск дороги в месіанські обрії, до воскресіння Правди в здоланні пекла "в тім раю"'" [22, с. 11]. Живопис Стороженка, присвячений шевченківським поезіям, розширює історично обумовлені академічні традиції Т. Шевченка в бік бароковості. Таким чином, як поезія, так і живопис Шевченка стають каталізатором нового словесно-живописного синтезу, де пророчість, теми самозаглиблення, смерті, страждань, воскресіння підіймають нові шари українських і світових традицій.

Месіанізм Тараса Шевченка пов'язаний з поверненням істинного розуміння євангельського вчення і Бога замість ідола, якого з нього зроблено зусиллями мирської влади та пануючої церкви. Образ співця-кобзаря допомагає йому на цьому шляху повернення до чистих в своїй людяності християнських джерел [9, с. 168].

Ярослав Грицак у своїй монографії про Івана Франка визначає такі складові постаті "митця-пророка", які показують вектори розвитку шевченківських ідей:

- надання митцем українському рухові добірки яскравих літературних образів, із яких проступали контури нової батьківщини;

- наявність біографії, яка б надавала добрий матеріал для культу національного поета, що мав уособлювати цю батьківщину;

- виховане ним покоління дбає про поширення його творів і популяризацію його культу [7, с. 431].

Висновок. Чим нам знадобиться зараз пророчий дух Шевченка? Його "...як німець покаже" завжди буде іронічним щепленням проти зарозумілого мавпування чужої мудрості. Але реалії правової держави з безособовою (отже, "німецькою") владою закону є досить далекими від ідеалу братерства поза соціальними ієрархіями, того ідеалу "сім'ї вольної, нової", яка була в поезіях Шевченка. Втім будь-які закони залишаються мертвою буквою без надихаючого пафосу моралі та справедливості. Об'єднуюча сила маленької згуртованої общини, яка бореться за соціальні права, лицарського братства, що захищає Вітчизну, завдяки пророчому духу Тараса Шевченка завжди буде протистояти спробам перетворити позірну букву законності у псевдошляхетський устрій на чолі з "недоторканними" чи "вертикаль", у якій "батьківська влада" розповсюджується лише на вузький клан людей, а для інших обертається жорстокою байдужістю, що приховується за святенництвом і лицемірством. Цікавим і неочікуваним $€$ порівняння фахівцями-фрілологами місії Тараса Шевченка 3 діяльністю Мартіна Лютера [13]. Останній робив спроби повернути християнство до його першоджерел. Тарас Шевченко прямував подібними шляхами, надаючи почуттям, мові, об'єднуючій громаду, силу біблійної пристрасті та християнської любові.

\section{СПИСОК ВИКОРИСТАНИХ ДЖЕРЕЛ}

1. Ауэрбах Эрих. Мимесис. Изображение действительности в западноевропейской литературе ; пер. с нем. / Э. Ауэрбах - М. : Прогресс, 1976. -560 с

2. Антонович Дмитро Володимирович. Шевченко-маляр / Д. В. Антонович. - К. : Україна, 2004. - 272 с.

3. Барабаш Ю. Людей і Господа любіть (любов як ментальна й поетична константа творчості Т. Шевченка) / Ю. Барабаш // Слово і час. 2007. - № 3. - С. 3-18.

4. Библейская энциклопедия. Репринтное издание. - М. : Терра, 1990. - 902 c.

5. Генералюк Леся. Універсалізм Шевченка: Взаємодія літератури і мистецтва / Л. Генералюк. - К. : Наук. думка, 2008. - 544 с.

6. Грицак Я. Пророк у своїй вітчизні. Франко та його спільнота (1856-1886) / Я. Грицак. - К. : Критика, 2006. - 431 с.

7. Гриценко О. "Своя мудрість": національні міфології та "громадянська релігія" в Україні /О. Гриценко. - К. : УЦКД, 1998. - 184 с. 
8. Демська-Будзуляк Л. Драма свободи в модернізмі. Пророчі голоси драматургії Лесі Українки / Л. Демська-Будзуляк. - К. : Академвидав, 2009. - 184 c.

9. Дзюба І. Бог, релігія, церква в житті і творчості Шевченка / І. Дзюба // Тарас Шевченко і народна культура. Зб. праць міжнар. 35-ї наук. Шевченківської конф. 20-22 квітня. - Черкаси, 2004. - С. 150-169.

10. Дзюба І. Шевченкофобія в сучасній Україні / І. Дзюба. - К. ВД "Києво-Могилянська академія", 2006. - 57 с.

11. Драгоманов М. Шевченко, українофіли і соціалізм / М. Драгоманов // Вибране (...мій задум зложити очерк історії цивілізації на Україні). - К. : Либідь, 1991. - С. 327-430.

12. Живов В. М. Пророк / В. М. Живов // Святость. Краткий словарь агиографических терминов. - М. : Гнозис, 1994. - 112 с.

13. Журавлев В.К. Язык. Языкознание. Языковеды

В. К. Журавлев. - М. : Наука, 1991. - 208 с.

14. Забужко О. Шевченків міф України. Спроба філософського аналізу / О. Забужко. - К. : Абрис, 1997. - 144 с.

15. Іванишин П. Вульгарний "неоміфологізм": від інтерпретації до фальсифікації Т. Шевченка / П. Іванишин. - Дрогобич : "Відродження", 2001. - $174 \mathrm{c}$.

16. Кондаков И. В. Интеллигенция / И.В.Кондаков // Культурология. XX век. Энциклопедия. - СПб. : Университетская книга, 1996. T. 1. $-447 \mathrm{c}$.

17. Костомаров М. І. Спогад про двох малярів / М. І. Костомаров // Світова велич Шевченка. 3б. матеріалів про творчість Т. Г. Шевченка у 3-х т. - К. : Держидав, 1964. - Т. 1. - 511 с.

18. Костомаров Н. И. Исторические произведения. Автобиография / Н. И. Костомаров. - К. : Изд-во при Киев. ун-те, 1989. - 736 с.

19. Кретов А. И. Тарас Шевченко: поэт и пророк / А. И. Кретов // Вечное слово. Фонд "Добро". - М. : 2002. - № 4. - С. 5-8.

20. Кубриш Н. Міфопоетика пам'ятників Тарасові Шевченку (На прикладі творчості Івана Кавалеридзе) / Н. Кубриш // Мистецькі обрії. Альманах. - 2004. - С. 107-115.

21. Российский телеканал назвал Тараса Шевченко второсортным поэтом и призвал не праздновать его 200 -летие [Електронний ресурс] // Корреспондент.net, 13 марта 2013, 10:25. - Режим доступу: http://korrespondent.net/ukraine/1521805-rossijskij-telekanal-nazval-tarasashevchenko-vtorosortnym-poetom-i-prizval-ne-prazdnovat-ego-200-let; https://www.youtube.com/watch?v=6tn7/5z-uOQ

22. Стороженко М. А. Мій Шевченко. Альбом / М. А. Стороженко К. : Грамота, 2011. $-212 \mathrm{c}$.

23. Тьоніс Ф. Спільнота та суспільство ; пер. з нім. / Ф. Тьоніс - К. Дух і літера, 2005. - 262 c.

24. Федевич К. К. За Віру, Царя і Кобзаря. Малоросійські монархісти і український національний рух / К. К. Федевич, К. І. Федевич. - К. Критика, 2017. - 230 с.

25. Шевченко Т. Кобзар / Т. Шевченко - К. : Держ. вид-во худ. літ., 1961. -608 c.

\section{REFERENCES}

1. Auerbah, E. (1976). Mimesis: The Representation of Reality in Western Literature. Moskow, Progress (In Russian).

2. Antonovich, D. V. (2004). Shevchenko-malyar [Shevchenko as a Painter]. Kyiv, Ukrayina.

3. Barabash, Yu. (2007). Lyudej i Gospoda lyubit (lyubov yak mentalna j poetichna konstanta tvorchosti T. Shevchenka) [Love people and God (love as a mental and poetic constant of T. Shevchenko's creativity)]. Slovo $i$ chas, № 3, 3-18. Terra.

4. Biblejskaya enciklopediya [Biblical encyclopedia] (1990). Moskow,

5. Generalyuk, L. (2008). Universalizm Shevchenka: Vzayemodiya literaturi i mistectva [Shevchenko's Universalism: The Interaction of Literature and Art]. Kyiv, Naukova dumka.

6. Gricak, Ya. (2006). Prorok u svoyij vitchizni. Franko ta jogo spilnota (1856-1886) [A prophet in his homeland. Franco and his community (18561886)]. Kyiv, Kritika.

\section{A. I. Kretov, $\mathrm{PhD}$, Senior lecturer}

National Academy of Creative Art and Architecture

20, Voznesenskiy uzviz, Kiev, 04053, Ukraine
7. Gricenko, O. (1998). "Svoya mudrist": nacionalni mifologiyi ta "gromadyanska religiya" v Ukrayini ["Our own wisdom": national mythologies and "civil religion" in Ukraine]. Kyiv, UCKD.

8. Demska-Budzulyak, L. (2009). Drama svobodi $v$ modernizmi. Prorochi golosi dramaturgiyi Lesi Ukrayinki [The drama of freedom in modernism. The prophetic voices of Lesya Ukrainka's drama]. Kyiv, Akademvidav.

9. Dzyuba, I. (2004). Bog, religiya, cerkva v zhitti i tvorchosti Shevchenka [God, religion, church in the life and creativity of Shevchenko]. Taras Shevchenko i narodna kultura. Zbirnik prac mizhnarodnoyi (35-yi) naukovoyi Shevchenkivskoyi konferenciyi 20-22 kvitnya. Cherkasi, 150-169.

10. Dzyuba, I. (2006). Shevchenkofobiya $v$ suchasnij Ukrayini [Shevchenkophobia in modern Ukraine]. Kyiv, Vid. dim "Kyivo-Mogilyanska Akademiya".

11. Dragomanov, M. (1991). Shevchenko, ukrayinofili i socializm [Shevchenko, Ukrainophiles and Socialism ]. In Vibrane (...mij zadum zlozhiti ocherk istoriyi civilizaciyi na Ukrayini) [Selected works (...my idea is to compile an essay on the history of civilization in Ukraine)]. Kiyiv, Libid, $327-430$.

12. Zhivov, V. M. (1994). Prorok. [The Prophet ]. In Svyatost. Kratkij slovar agiograficheskih terminov. Moskow, Gnozis.

13. Zhuravlev, V. K. (1991). Yazyk. Yazykoznanie. Yazykovedy [Language. Linguistics. Linguists]. Moskow, Nauka.

14. Zabuzhko, O. (1997). Shevchenkiv mif Ukrayini. Sproba filosofskogo analizu [Shevchenko's myth of Ukraine. An attempt at philosophical analysis ]. Kyiv, Abris.

15. Ivanishin, P. (2001). Vulgarnij "neomifologizm": vid interpretaciyi do falsifikaciyi T. Shevchenka [Vulgar "neomythologism": from interpretation to falsification of Taras Shevchenko]. Drogobich, Vidrodzhennya.

16. Kondakov, I. V. (1996). Intelligenciya [Intelligence]. In Kulturologiya. $X X$ vek. Enciklopediya. [Culturology of the twentieth century. Encyclopedia]. Sankt-Petersburg, Universitetskaya kniga, Vol. 1.

17. Kostomarov M. I. (1964). Spogad pro dvoh malyariv [Memoirs of two painters]. Svitova velich Shevchenka. Zbirnik materialiv pro tvorchist T. G. Shevchenka. [World greatness of Shevchenko. Collection of materials about the work of T.G. Shevchenko]. Kyiv, Derzhidav. Vol. 1.

18. Kostomarov, N.I. (1989). Istoricheskie proizvedeniya. Avtobiografiya [Historical works. Autobiography]. Kiev, Izd-vo pri Kiev. un-te.

19. Kretov, A. I. (2002). Taras Shevchenko: poet i prorok. [Taras Shevchenko: poet and prophet ]. Vechnoe slovo. Fond "Dobro". [The Eternal Word. "Good" Foundation]. Moskow, № 4, 5-8.

20. Kubrish, N. (2004). Mifopoetika pam'yatnikiv Tarasovi Shevchenku (Na prikladi tvorchosti Ivana Kavaleridze) [Mythopoetics of monuments to Taras Shevchenko (On the example of the work of Ivan Kavaleridze)]. Mistecki obriyi. Almanah, 107-115.

21. Rossijskij telekanal nazval Tarasa Shevchenko vtorosortnym poetom i prizval ne prazdnovat ego 200-letie. [Russian TV channel called Taras Shevchenko a second-rate poet and urged not to celebrate his 200th anniversary]. Korrespondent.net (March, 13, 2013). Retrieved from http://korrespondent.net/ukraine/1521805-rossijskij-telekanal-nazval-tarasashevchenko-vtorosortnym-poetom-i-prizval-ne-prazdnovat-ego-200-let; https://www.youtube.com/watch?v=6tn7l5z-uOQ

22. Storozhenko, M. A. (2011). Mij Shevchenko [My Shevchenko]. Kyiv, Gramota.

23. Tönnies, F. (2005). Community and Civil Society. Kyiv, Duh i litera (In Ukrainian).

24. Fedevich, K. K., Fedevich, K. I. (2017). Za Viru, Carya i Kobzarya. Malorosijski monarhisti i ukrayinskij nacionalnij ruh [For Faith,Tsar and Kobzar. Little Russian monarchists and the Ukrainian national movement]. Kyiv, Kritika.

25. Shevchenko, T. (1961). Kobzar. Kyiv, Derzh. vidav. hud. lit.

Надійшла до редколегії 29.10.20

\section{THE HERITAGE OF TARAS SHEVCHENKO: THE IMAGE OF THE "ARTIST-PROPHET" IN UKRAINIAN CULTURE}

The article is devoted to the problem of the image of the artist as a prophet in connection with the work of Taras Shevchenko, due to his extraordinary influence on Ukrainian culture. The formation of this image is the result of the interaction of a number of socio-cultural factors, which are the subject of analysis in this article. First of all, it is the dependence of the Great Kobzar's self-determination on those strategies that depend on poetry and painting, the place of these spheres in contemporary society, their task of integrating creative activity into the social structure and artistic environment, the importance of skill and order. Secondly, the echo in the Shevchenko era of the ideas of the Enlightenment with their universalist claims and the emergence of a phenomenon in the Russian Empire, which was called "intelligentsia", formed against the background of cultural "literary centrism". Third is the influence of romanticism on the artist's idea of leading the process of forming a certain community, which is not associated with social inequality and formal hierarchies in society. Fourth is the dependence of the artist image - the prophet with the intertwining of Christian and pagan roots of Ukrainian culture. It is shown that the archetype of the national artist-prophet created by $T$. Shevchenko's successors survived situations of imitation, affirmation, rethinking, even denial. Such a diverse dialogue testifies to the urgency of Taras Shevchenko's legacy. The article shows that there is an urgent need to study the figure of Shevchenko in the context of world culture, the functioning of the model "artist - prophet" in general and in their own country. It is also important to give this problem a philosophical depth. It is necessary to comprehend the models through which they tried to attract the figure of Shevchenko to various ideologies, that is, to give it a certain "plane" and "one-dimensionality." And "one-dimensional" Taras Shevchenko is a model that is too easy to manipulate.

Key words: artist as a prophet, poet, painter, community, society, "intelligentsia", literary centrism. 
А. И. Кретов, канд. филос. наук, ст. препод.

Национальная академия изобразительного искусства и архитектуры,

ул. Вознесенский спуск, 20, г. Киев, 04053, Украина

\section{НАСЛЕДИЕ ТАРАСА ШЕВЧЕНКО: ОБРАЗ "ХУДОЖНИКА-ПРОРОКА" В УКРАИНСКОЙ КУЛЬТУРЕ}

Статья посвящена проблеме образа художника как пророка в связи с творчеством Т. Шевченко, вследствие его беспрецедентного влияния в украинской культуре. Формирование этого образа является результатом взаимодействия ряда социокультурных факторов, которые и являются предметом анализа в данной статье. Прежде всего, это обусловленность самоопределения Великого Кобзаря теми стратегиями, которые зависят от поэзии и живописи, места этих сфер в обществе того времени, заданной ими меры интегрированности творческой деятельности в социальную структуру и художественную среду, значения для них мастерства и заказа. Во-вторых - отзвук в шевченковскую эпоху идей Просвещения $c$ их универсалистскими претензиями и становление в Российской империи феномена, который получил название "интеллигенции" и формировался на фоне культурного "литературоцентризма". Третье - влияние романтизма на идею творца как лидера в процессе формирования определенной общности, которая не связана с социальным неравенством и формальными иерархиями в обществе. Четвертое - это зависимость образа художника-пророка с переплетением языческих и христианских корней украинской культуры. Показано, что в последователей Т. Шевченко созданный им архетип национального художника-пророка пережил ситуации подражания, утверждения, переосмысления, даже отрицания. Такой разнообразный диалог во времени свидетельствует об актуальности наследия Т. Шевченко.

Ключевые слова: художник как пророк, художник, поэт, общность, общество, интеллигенция, литературоцентризм.

УДК 113/119:159.923.2

В. П. Культенко, канд. філос. наук, доц. Національний університет біоресурсів і природокористування України, вул. Героїв Оборони, 15, м. Київ, 03041, Україна kultenko@ukr.net

\section{ДО ПРОБЛЕМИ ФОРМУВАННЯ СИНЕРГЕТИЧНОЇ МОДЕЛІ НЕЛІНІЙНОÏ ОСОБИСТОСТІ}

Досліджено виховний, освітній і психологічний потенціали синергетики у формуванні сучасної нелінійної особистості. Синергетика розглядається як методологія розв'язання психофізіологічних, освітніх, соціальних, комунікативних та інших проблем сучасності. 3 позиції психосинергетики психіка людини розглядається як відкрита гіперсистема синергетичного порядку, що має фазову структуру та перебуває в неврівноваженому стані. Система в неврівноважених умовах поводить себе принципово інакше та потребує засобів самозбереження, самоналаштування. Зіштовхуючись із новими для себе ситуаціями, люди реагують на них нетипово й гостро потребують вироблення нових психологічних, освітніх і поведінкових стратегій, які забезпечує синергетика. Відстоюється положення про те, що сучасний світ - це світ системної кризи в найрізноманітніших сферах життя. Такий світ потребує системного холістичного мислення, єдності фундаментальних теоретичних і практичних прикладних знань $і$ вмінь, творчого підходу та нелінійності мислення при розв'язанні проблем.

Ключові слова: синергетика, нелінійна особистість, холізм, творче мислення, виховання, освіта.

Постановка проблеми. Сучасні фрілософські рефрлексії просякнуті ідеєю системної кризи, в якій перебуває людство впродовж досить тривалого часу. Стрімкі зміни, що відбуваються у світі, не поліпшують, а, навпаки, часто посилюють ситуацію кризи. Людина перманентно перебуває у просторі ескалації, катастроф, глобальних небезпек. Стан світу, в якому існує людина, змінився. Найбільші зміни пов'язані з процесами глобалізації та спровокованими нею наслідками - часто неочікувано негативними й загрозливими. Найяскравіше підтвердження тому - пандемія коронавірусу та поставлені нею виклики людству, які потребують негайної реакції, ухвалення стратегічних рішень у найкоротші терміни в ім'я виживання людства. Ситуація потребує зміни стану і самої людини, оскільки, будучи нерозривно пов'язаною зі світом, вона має пристосовуватись до нього. Пристосовуватись і тоді, коли зміни зовнішнього середовища спричинені самою ж людиною.

Аналіз досліджень і публікацій. У творчості ряду фрілософрів артикулюються проблеми кризи культури (В. Хексле, Ю. Хабермас, Ф. Хоркхаймер, Т. Адорно, М. Вебер, Д. Лукач та ін.), "колапсу рішень" (Дж. Надлер, Ш. Хібіно, Дж. Фаррелл), антропогенетичної кризи (А. Арсеньєв, В. Семенов та ін.), кризи "недосконалого суспільства" (А. Печчеї, Е. Гідденс, У. Бек) тощо.

Мета статті. Дослідити виховний, освітній та психолого-терапевтичний потенціал синергетики, її спроможність сприяти фрормуванню сучасної нелінійної особистості, здатної адекватно реагувати на виклики світу.

Виклад основного матеріалу дослідження. Початок XXI ст. чітко засвідчив потребу людства у принципово нових інформаційно-емоційних мисленнєвих, світоглядних, етичних та поведінкових стратегіях як у вимірах внутрішньо-індивідуального буття людини, так і на рівні соціальних взаємодій. Особливо загострилось питання формування людини, здатної мислити нелінійно, творчо, критично, системно, сприймати світ у вимірах, пропонованих синергетикою. Сучасний світ потребує нелінійних особистостей. Адже суттєвою характеристикою сьогоднішнього життя $є$ різке збільшення швидкості та інтенсивності інфрормаційних процесів, які супроводжуються нелінійними змінами соціально-політичних, економічних, валеологічних, культурних та психологічних параметрів середовища людського існування.

Автор психосинергетичної моделі особистості, проф. І. Єршова-Бабенко, використовує синергетичну термінологію, а саме поняття "середовище у середовищі", "ціле у цілому", для позначення становлення людини як нелінійного цілого мікросередовища у нелінійному цілому середовищі макросвіту. Дослідниця наполягає на базовому положенні цих понять у концепції нелінійного мислення, водночас застерігаючи про небезпеки, які виникають в антропологічній сфері при їхньому некритичному використанні. Постійно змінний характер процесів макросередовища украй виснажливий для людини, оскільки "психологічним рефреном емоційного стану людини в цьому випадку стає страх "не встигнути", страх "не відповідати" [1]. Авторка визначає психосинергетику як площину, де сконцентровано увагу на стані внутрішнього психічного середовища людини в аспекті його нелінійності та продуктивної хаотичності. Це дозволяє їй існувати в умовах різного ступеня хао- 